Int. J. Dev. Biol. 58: 291-298 (2014)

doi: $10.1387 / \mathrm{ijdb} .140077 \mathrm{mb}$

\title{
Epigenetics and imprinting in human disease
}

\author{
JENNIFER M. KALISH, CONNIE JIANG and MARISA S. BARTOLOMEI* \\ Department of Cell \& Developmental Biology, Perelman School of Medicine at the University of Pennsylvania, \\ Philadelphia, Pennsylvania, USA
}

\begin{abstract}
Most genes are expressed from both parental chromosomes; however, a small number of genes in mammals are imprinted and expressed in a parent-of-origin specific manner. These imprinted genes play an important role in embryonic and extraembryonic growth and development, as well as in a variety of processes after birth. Many imprinted genes are clustered in the genome with the establishment and maintenance of imprinted gene expression governed by complex epigenetic mechanisms. Dysregulation of these epigenetic mechanisms as well as genomic mutations at imprinted gene clusters can lead to human disease.
\end{abstract}

KEY WORDS: genomic imprinting, DNA methylation, Beckwith-Wiedemann syndrome, Russell-Silver syndrome

\section{Introduction}

Genes that are subject to genomic imprinting are expressed exclusively or predominately from a single parental chromosome (Bartolomei, 2009). Among animals, this curious phenomenon has been described only in mammals, although plants such as Arabidopsis have imprinted genes, and other organisms, including arthropods, exhibit parental-specific behavior of entire chromosomes. The murine genome contains $\sim 150$ imprinted genes, (a complete up-to-date list of imprinted genes can be found here: http://www. mousebook.org/catalog.php?catalog=imprinting; (Williamson etal., 2014)). Importantly, imprinting is well-conserved across mammals, with many imprinted genes and most imprinting mechanisms conserved between mouse and human (Lee and Bartolomei, 2013).

Most imprinted genes are present in distinct clusters that are about $1 \mathrm{Mb}$ in length and contain both maternally and paternally expressed genes (Fig. 1). In addition to protein-coding genes in these clusters, there are typically long noncoding RNAs (ncRNA), some of which regulate the imprinting of the nearby genes. Regulation of the clustered genes is coordinated through short DNA sequences called imprinting control regions (ICRs). All ICRs identified thus far are differentially methylated regions (DMRs) in which DNA is methylated on one parental allele. As described in more detail below, DNA methylation usually represses either a long ncRNA or an insulator, which mediates the imprinting across the locus.

A significant consequence of imprinting is that mammalian development requires genetic contributions from both a mother and a father (McGrath and Solter, 1984, Solter, 1988). In humans, uniparental conceptuses arise at a very low frequency and have distinct phenotypes. Embryos with two paternal genomes and no maternal contribution (androgenotes) produce hydatidiform moles that are comprised of extraembryonic membranes while embryos with only maternal genomes (gynogenotes) result in ovarian teratomas that are comprised of embryonic cell types. Several live-born individuals have been reported with mosaic genome-wide paternal uniparental isodisomy (Gogiel et al., 2013, Inbar-Feigenberg et al., 2013, Kalish et al., 2013). In these cases, in some cells the entire maternal haplotype is lost and the paternal haplotype is duplicated, resulting in paternal uniparental isodisomy for the entire genome. These individuals have a mixture of normal biparental lineage cells and paternal uniparental cells in each tissue. Most of these individuals had enlarged extraembryonic tissues and were large conceptuses (phenotype is described in more detail below).

Experimental manipulation in the mouse using nuclear transfer showed that embryos reconstructed from two maternal pronuclei (gynogenetic embryos) or two paternal pronuclei (androgenetic embryos) failed to survive; whereas embryos reconstructed from one maternal and one paternal pronucleus produced viable and fertile offspring (McGrath and Solter, 1984, Solter, 1998). Gynogenetic embryos at the time of death were once again defective in extraembryonic tissues that contribute to the placenta, whereas androgenetic embryos were defective in embryonic tissue. These

\footnotetext{
Abbreviations used in this paper: ART, assisted reproductive technologies; AS, Angelman syndrome; BWS, Beckwith-Wiedemann syndrome; CTCF, CCCTC-binding factor; DMR, differentially methylated region; DNMT, DNA methyltransferase; GOM, gain of methylation; IC1, imprinting control region 1; IC2, imprinting control region 2; ICR, imprinting control region; LOM, loss of methylation; ncRNA, noncoding RNA; PWS, Prader-Willi Syndrome; RSS, Russell-Silver syndrome; TET, ten-eleven translocation; UPD, uniparental disomy.
}

\footnotetext{
*Address correspondence to: Marisa S. Bartolomei. 9-123 Smilow Center forTranslational Research, 3400 Civic Center Blvd, Philadelphia, PA 19104, USA. Tel: +1-215-898-9063. E-mail: bartolom@mail.med.upenn.edu

Final, author-corrected PDF published online: 8 July 2014.
}

ISSN: Online 1696-3547, Print 0214-6282 
outcomes led to the hypothesis that embryonic development requires imprinted genes expressed from the maternal genome, whereas the paternal genome expresses imprinted genes required for extraembryonic development (Barton et al., 1984). However, subsequent identification of imprinted genes in the mouse did not confirm such a bias in the function of imprinted genes, suggesting a less simple explanation for uniparental developmental outcomes. In fact, while imprinted genes have a prominent role in embryonic growth and placental development, they also play central roles in postnatal energy homeostasis and behavior (Fig. 2). Nevertheless, numerous imprinted genes have been identified that are placentaspecific, suggesting independent requirements for imprinted genes in embryonic versus extraembryonic lineages.

In addition to the necessity of both parental complements for appropriate development, deletions or mutations in specific imprinted genes cause a number of human imprinting disorders (Table 1). For example, failure to express the paternal allele or maternal allele of genes within the SNRPN imprinted domain results in Prader-Willi Syndrome (PWS) and Angelman Syndrome (AS), respectively. Moreover, genetic or epigenetic abnormalities in the H19/IGF2 or KCNQ1 domains result in Beckwith-Wiedemann Syndrome (BWS) or Russell-Silver Syndrome (RSS), depending on which parental allele is affected.

\section{Establishment and maintenance of imprints}

The key to the imprinting of genes in clusters is the consistent parental-specific epigenetic marking of the ICR as well as the

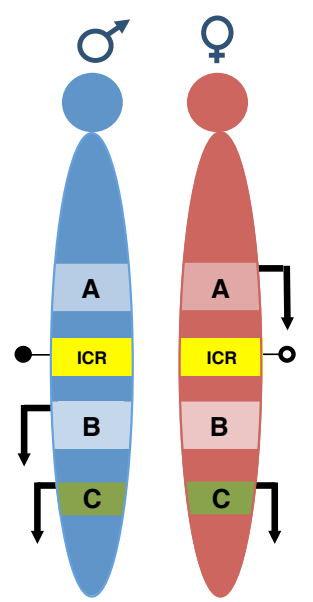

Fig. 1. Imprinted gene expression. Paternal (blue) and maternal (red) chromosomes are shown with expressed alleles indicated with an arrow. Methylation as designated by the filled circle at the imprinting control region (ICR, yellow box) leads to repression of gene $A$ and expression of gene $B$ from the paternal allele. Absence of methylation (open circle at ICR) on the maternal allele leads to expression of gene $A$ and repression of gene $B$. Gene $C$ is biallelically expressed.

subsequent maintenance of allele-specific epigenetic modifications. As described in more detail below, ICR deletions and aberrant allele-specific DNA methylation are associated with loss of imprinting of the linked genes in the clusters and, in the case of humans, imprinting disorders.

Although other epigenetic mechanisms such as post-translational histone modifications may also play a role in the parental-specific epigenetic mark, differential DNA methylation is the best recognized modification for conferring parental identity. DNA methyltransferases (DNMTs) have been demonstrated to have a role in both establishment and maintenance of DNA methylation based on mouse models where mutations in these genes lead to loss of ICR

TABLE 1

IMPRINTED GENE CLUSTERS IN HUMANS

\begin{tabular}{|c|c|c|c|c|c|c|}
\hline $\begin{array}{l}\text { Imprinted } \\
\text { Gene Loci }\end{array}$ & $\begin{array}{l}\text { Associated Imprinted } \\
\text { ncRNAs }\end{array}$ & $\begin{array}{l}\text { Other Associated Imprinted } \\
\text { Genes }\end{array}$ & Germline DMRs & $\begin{array}{l}\text { Imprinting } \\
\text { Mechanism }\end{array}$ & $\begin{array}{l}\text { Human Locus } \\
\text { (Mouse Locus) }\end{array}$ & $\begin{array}{l}\text { Association with Human Disease } \\
\text { or Syndrome }\end{array}$ \\
\hline IGF2 & $\mathrm{H} 19$ & INS2 & H19 ICR (IC1 in humans) & $\begin{array}{l}\text { CTCF-dependent } \\
\text { insulator }\end{array}$ & $11 \mathrm{p} 15.5$ (7qF5) & $\begin{array}{l}\text { Beckwith-Wiedemann syndrome (BWS), } \\
\text { Russell-Silver syndrome (RSS) }{ }^{1}\end{array}$ \\
\hline CDKN1C & KCNQ1OT1 & $\begin{array}{l}\text { KCNQ1, OSBP15, NAP114, } \\
\text { PHLDA2, SLC22A18, MSUIT1, } \\
\text { CD81, ASCL2, TSSC4 }\end{array}$ & $\begin{array}{l}\text { KCNQ1OT1 promoter: KvDMR1 (IC2 in } \\
\text { humans) }\end{array}$ & $\begin{array}{l}\text { long ncRNA } \\
\text { transcription }\end{array}$ & $11 \mathrm{p} 15.4(7 \mathrm{qF} 5)$ & Beckwith-Wiedemann syndrome (BWS) ${ }^{1}$ \\
\hline SNRPN & UBE3AATS/snoRNAs & $\begin{array}{l}\text { ATP10A, UBE3A, SNURF, } \\
\text { NDN, MAGEL2, MKRN3, } \\
\text { PEG12 }\end{array}$ & $\begin{array}{l}\text { SNRPN exon } 1 \text { and putative } \\
\text { transcription start site SNRPN promoter } \\
\text { and exon 1: PWSIC (ICR) }\end{array}$ & $\begin{array}{l}\text { long ncRNA } \\
\text { transcription? }\end{array}$ & $15 q 11.2(7 q B 5)$ & $\begin{array}{l}\text { Prader-Willi syndrome (PWS), Angelman } \\
\text { syndrome (AS) }{ }^{2}\end{array}$ \\
\hline ZAC (PLAGL1) & HYMAI & & HYMAI exon 1 & ND & $6 q 24.2(10 q A 2)$ & $\begin{array}{l}\text { Transient neonatal diabetes mellitus, } \\
\text { neoplasia }^{3}\end{array}$ \\
\hline $\begin{array}{l}\text { GNAS } \\
\text { (NESP55) }\end{array}$ & $\begin{array}{l}\text { GNAS exon } 1 \text { A/B, } \\
\text { GNAS (XLAS), } \\
\text { GNASAS, NESPAS }\end{array}$ & GNASX1, NESP & $\begin{array}{l}\text { GNASXI and } \\
\text { NESPAS promoter DMR (primary ICR), } \\
\text { GNAS exon 1a promoter DMR } \\
\text { (secondary ICR) }\end{array}$ & ND & $20 \mathrm{q} 13.32(2 \mathrm{qH} 4)$ & $\begin{array}{l}\text { Cushing's syndrome, McCune-Albright } \\
\text { syndrome, progressive osseous } \\
\text { heteroplasia, pseudohypoparathyroidism } \\
\text { (la, Ib, Ic), somatotroph adenoma, } \\
\text { Albright hereditary osteodystrophy }{ }^{4}\end{array}$ \\
\hline DLK1 & $\begin{array}{l}\text { MEG3 (GTL2), anti- } \\
\text { RTL1 microRNAs, Rian } \\
\text { snoRNAs, Mirg } \\
\text { microRNAs }\end{array}$ & RTL1, DIO3 & $\begin{array}{l}\text { GTL2 DMD/ICR Intergenic DMR: IG- } \\
\text { DMR (ICR) }\end{array}$ & $\begin{array}{l}\text { CTCF-dependent } \\
\text { insulator ND }\end{array}$ & $14 q 32.2(12 q F 1)$ & $\begin{array}{l}\text { UPD14, facial dysmorphisms, skeletal } \\
\text { abnormalities }^{5}\end{array}$ \\
\hline PEG3 & & $\begin{array}{l}\text { ZIM2, ZIM1, USP29, ZIM3, } \\
\text { ZFP264 }\end{array}$ & PEG3 promoter and exon 1 & ND & $19 q 13.43(7 q A 1)$ & $\begin{array}{l}\text { Ovarian cancer, choriocarcinomas, } \\
\text { oligodendrogliomas, hydatidiform moles }\end{array}$ \\
\hline PEG10 & & SGCE, PPP1R9A, ASB4 & PEG10 and SGCE promoter & ND & $7 q 21.3(6 q A 1)$ & $\begin{array}{l}\text { Myoclonus-dystonia syndrome, } \\
\text { hepatocellular carcinoma }^{7}\end{array}$ \\
\hline MEST (PEG1) & COPG2AS & COPG2, KLF14 & MEST-promoter exon 1 & ND & $7 q 32.2(6 q A 3.3)$ & Russell-Silver syndrome (RSS) $?^{8}$ \\
\hline RASGRF1 & $\begin{array}{l}\text { 4930524O08Rik } \\
\text { (mouse) }\end{array}$ & & -30 kb RASGRF1 DMR-Repeat (ICR) & $\begin{array}{l}\text { CTCF-dependent } \\
\text { insulator? }\end{array}$ & $15 q 25.1(9 q E 3.1)$ & $\begin{array}{l}\text { alveolar rhabdomyosarcoma, myopia, } \\
\text { epilepsy, gastric cancer }\end{array}$ \\
\hline GRB10 & & GRB10 brain isoform & GRB10 CpG Island 2 & ND & $7 p 12.2(11 q A 1)$ & $\begin{array}{l}\text { Russell-Silver syndrome (RSS)?, } \\
\text { Albright's hereditary osteodystrophy, } \\
\text { Hirschsprung disease, } \\
\text { squamous cell cancers }^{10}\end{array}$ \\
\hline
\end{tabular}

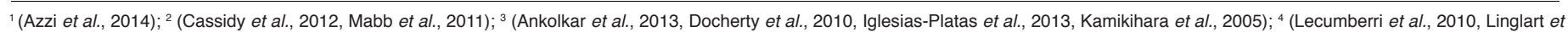

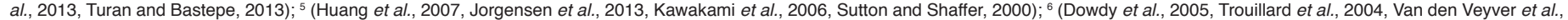

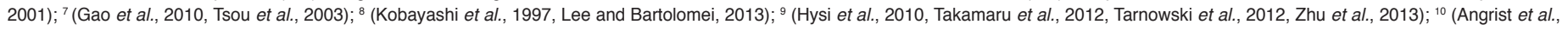
1998, Arnaud et al., 2003, Okino et al., 2005). 
methylation and biallelic expression of imprinted genes (Kaneda et al., 2004). Through the use of the de novo DNA methyltransferases DNMT3A and DNMT3B and the accessory protein DNMT3L, ICRs and DMRs are specifically methylated in the male or female germline (Bartolomei and Ferguson-Smith, 2011). Curiously, most of these regions are methylated in the oocyte postnatally during oocyte growth prior to ovulation. In contrast, a few ICRs, including the H19/lgf2 ICR, are methylated in the male germline prenatally.

The differential epigenetic modifications that are placed on the ICRs in the germline must be maintained following fertilization, despite the extensive reprogramming that takes place to prepare the genomes for embryonic development (Weaver et al., 2009). Here, the paternal genome undergoes active demethylation, in part through the action of the ten-eleven translocation (TET) gene family member TET3, which converts 5-methylcytosine to 5-hydroxymethylcytosine ( $\mathrm{Gu}$ et al., 2011), while the maternal genome undergoes passive demethylation with the pattern being lost through multiple cell divisions.

One of the least understood aspects of imprinting is how ICRs maintain their differential methylation during the post-fertilization reprogramming period. It is likely that a combination of cis-acting sequences and trans-acting factors mediates the protection. One maternal factor, PGC7/STELLA, appears to have a general role in maintaining DNA methylation in the early mouse embryo through interactions with dimethylated histone 3, lysine 9 (Nakamura et al., 2012). However, a factor that may be more specific for imprinted genes is ZFP57. Studies have demonstrated that ZFP57mutations identified in transient neonatal diabetes patients are associated with defects in DNA methylation at multiple imprinted loci (Mackay et al., 2008). Additionally, Zfp57 null mice exhibit embryonic lethality and loss of imprinting at many (but not all) loci (Li et al., 2008). It has recently been shown that ZFP57 binds to KAP1, which can then recruit other epigenetic regulators (Quenneville et al., 2011). Thus, sequence- and DNAmethylation-dependent binding of ZFP57, could act as an anchor to specify allelic binding of KAP1, which would subsequently recruit other major epigenetic regulators. It is possible that other yet-to-be-identified proteins also maintain DNA methylation at imprinted loci in the early embryo.

Intriguingly, the extraembryonic and embryonic tissues may use different mechanisms to maintain imprinting, as demonstrated by experiments assaying imprinted gene expression in mice that are deficient for the maintenance DNA methyltransferase, DNMT1 (Lewis et al., 2004, Umlauf et al., 2004, Weaver et al., 2010). These experiments show that placenta-specific imprinted genes in the Kcnq1 cluster, including Osbp/5, Tssc4, Cd81, and Ascl2, maintain imprinting in the absence of DNMT1. These genes are differentially marked by histone modifications in the placenta, with active histone modifications on the expressed maternal allele and repressive marks on the silent paternal allele (Lewis et al., 2004, Umlauf et al., 2004). These observations have led to the proposal that somatic DNMT1 is not required for maintenance of imprinting of these genes, which are instead regulated by post-translational histone modifications.

\section{Regulation of imprinting in clusters}

Two main regulatory mechanisms have been described for mediating imprinting in clusters (Bartolomei, 2009, Lee and Bartolomei, 2013). The first is the insulator model of imprinting, which is employed by the H19/lgf2 imprinted locus (Fig. 3A). The maternally

\begin{tabular}{|c|c|c|c|}
\hline Gene & Expressed Allele & Function of Gene Product & Role in Embryo \\
\hline IGF2 & Paternal & Positive regulator of general growth & Growth \\
\hline H19 & Maternal & Negative regulator of general growth & Suppression of growth \\
\hline IGF2R & Maternal & Negative regulator of general growth & Suppression of growth \\
\hline GRB10 & Maternal & Negative regulator of general growth & Suppression of growth \\
\hline GRB10 & Paternal & Signal adaptor & Aggression \\
\hline UBE3A & Maternal & $\begin{array}{l}\text { Ubiquitin ligase \& transcriptional co- } \\
\text { activator }\end{array}$ & $\begin{array}{l}\text { Memory, learning, } \\
\text { motor function }\end{array}$ \\
\hline PEG3 & Paternal & $\begin{array}{l}\text { Zinc finger protein; control of } \\
\text { apoptosis }\end{array}$ & Sex-specific behavior \\
\hline NDN & Paternal & $\begin{array}{l}\text { Regulator of neuronal growth and } \\
\text { differentiation }\end{array}$ & $\begin{array}{l}\text { Spatial learning; } \\
\text { socialization }\end{array}$ \\
\hline NESP & Maternal & Secretory pathway & Exploratory behavior \\
\hline GNAS & Maternal & Signal transduction & Cognition \& sleep \\
\hline
\end{tabular}

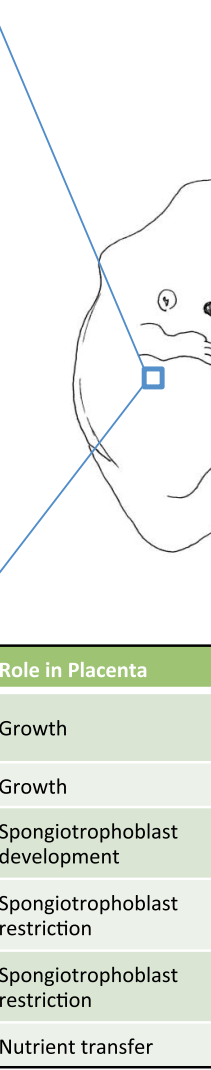

\begin{tabular}{|l|l|l|}
\hline Expressed Allele & Function of Gene Product & Role in Placenta \\
\hline Paternal & $\begin{array}{l}\text { Zinc finger protein; control of } \\
\text { apoptosis }\end{array}$ & Growth \\
\hline Paternal & Hydrolase & Growth \\
\hline Maternal & Helix-loop-helix transcription factor & $\begin{array}{l}\text { Spongiotrophoblast } \\
\text { development }\end{array}$ \\
\hline Maternal & Pleckstrin homology domain protein & $\begin{array}{l}\text { Spongiotrophoblast } \\
\text { restriction }\end{array}$ \\
\hline Maternal & Cell cycle regulator & $\begin{array}{l}\text { Spongiotrophoblast } \\
\text { restriction }\end{array}$ \\
\hline & Cation transporter & Nutrient transfer \\
\hline
\end{tabular}


expressed $\mathrm{H} 19$ gene and paternally expressed lgf2 gene share enhancers and their reciprocal imprinting is governed by the CCCTC binding factor (CTCF)-dependent insulator that is located between the genes. On the maternal allele in mouse, CTCF binds to 4 binding sites within the ICR, generating an insulator that prevents Igf2 from accessing the shared enhancers that are located on the H19 side of the insulator. On the paternal chromosome, methylation at the ICR prevents CTCF from binding, allowing Igf2 to engage

the enhancers. DNA methylation also silences the $H 19$ promoter on the paternal allele. Note that this locus is similarly regulated in human, with the main difference being that the ICR (designated IC1) is larger and contains 7 CTCF sites.

A more commonly utilized mechanism of imprinting employs long ncRNAs. An example of such a locus is the Kcnq1 locus (Fig. 3A), which encodes the paternally expressed long ncRNA, Kcnq1ot1. Regulation of this cluster also appears to be similar in mouse and human, although the mechanism has been largely elucidated in mouse models. In this case, the ICR (designated KvDMR1 in mouse and IC2 in human) includes a differentially methylated promoter that regulates the expression of the ncRNA (Konq1ot1); when unmethylated, the ncRNA is expressed and represses cis-linked genes. In contrast, when the ICR is methylated, the ncRNA is repressed and the cis-linked genes are expressed. How

B. BWS: Maternal IC2 LOM: $50 \%$

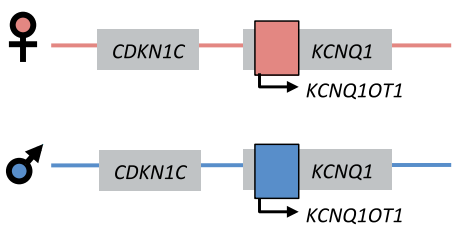

D. BWS: Paternal 11p15 uniparental disomy: $20 \%$

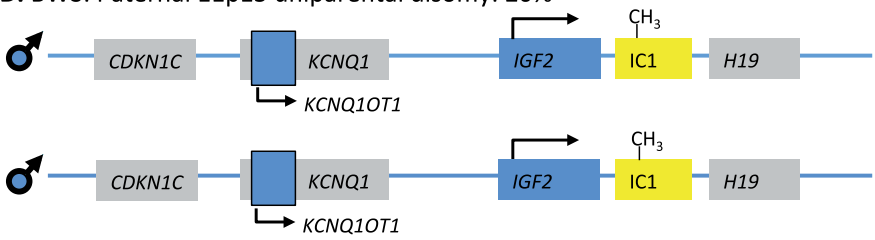

E. RSS: Paternal IC1 LOM: 50\%

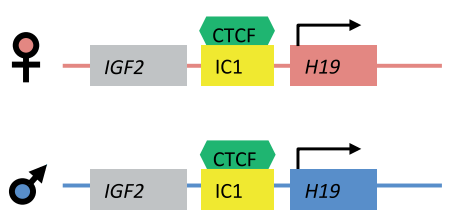

F. RSS: Maternal 11p15 uniparental disomy

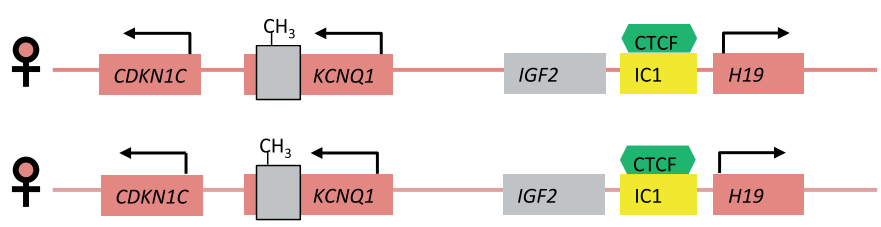

Fig. 3. Genetic and epigenetic alterations leading to Beckwith-Wiedemann syndrome (BWS) and Russell-Silver syndrome (RSS). (A) Normal imprinting and methylation at the 11p15 locus. (B) Hypomethylation at the human ICR (IC2) in the KCNQ1 locus leading to BWS. (C) Hypermethylation at IC1 in the H19/GF2 locus leading to BWS. (D) Paternal uniparental disomy leading to BWS. (E) Hypomethylation at IC1 leading to RSS. (F) Maternal uniparental disomy leading to RSS. Additional alterations at this locus leading to BWS include maternally transmitted inactivating mutations in CDKN1C, paternally transmitted duplications of the whole region or of IC1 alone, maternally transmitted microdeletions in IC1, and maternally transmitted deletions in IC2. RSS can also be due to activating mutations in CDKN1C or maternally transmitted duplications of the whole region or of IC2 alone.

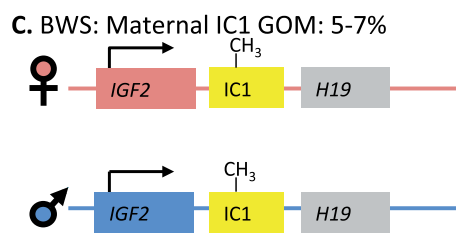

the ncRNA silences genes in cis is unclear. One idea is that the ncRNA attracts repressive chromatin machinery, as reported for the interaction of the Airn ncRNA with the histone methyltransferase G9Aat the Igf2rimprinted locus (Nagano et al., 2008). Alternatively, transcription through the domain, displacing transcriptional machinery such as RNA polymerase II, has likewise been suggested to silence genes in cis (Latos et al., 2012). It is also possible that both mechanisms are used, but in a tissue-specific manner.

\section{Role of imprinting in human disease}

In humans, six imprinted regions have been consistently associated with disease. Many of these imprinting disorders cannot be explained by absence of a single gene product. In fact, the phenotypic diversity associated with each syndrome is consistent with absence of expression or mis-expression of multiple genes in the relevant region. Mis-expression can be due to mutations in imprinted genes, methylation defects at ICRs or other regulatory regions, or uniparental disomy (UPD), where an imprinted chromosomal region from one parent is replaced by the same chromosomal region from the other parent. In some cases, overexpression of paternally expressed genes leads to disease, for example, on chromosome $6 q 24$ resulting in transient neonatal diabetes mellitus type I (Docherty et al., 2010). Alternatively, the failure to express the maternal alleles can lead to disease, as demonstrated by chromosome 20q13.32 where loss of maternal gene expression causes pseudohypoparathyroidism (Lecumberri et al., 2010). In some cases the causal change - overexpression or loss of expression is unclear as demonstrated by paternal uniparental disomy on chromosome14q32, which leads to facial dysmorphisms and skeletal findings including a bell-shaped thorax and "coat-hanger" ribs (Sutton and Shaffer, 2000). In still other cases, paternal mis-expression or maternal misexpression at the same genetic locus can cause distinct disorders. Failure to express the maternal allele of UBE3A on chromosome $15 q 11.2$ leads to Angelman syndrome, 
characterized by ataxic movements, developmental delay, intellectual disability, and epilepsy (Mabb et al., 2011). Conversely, failure to express the paternal alleles in the same region leads to Prader-Willi syndrome, characterized by hypotonia, mental retardation, short stature, hypogonadotropic hypogonadism, small hands and feet, and obesity (Cassidy et al., 2012). Additionally, there are two imprinting disorders caused by genetic or epigenetic changes in the same region of chromosome 11 that result in opposite growth phenotypes (Fig. 3 B-F). Russell-Silver syndrome (RSS), an undergrowth disorder, is due to overexpression of maternal alleles and loss of paternal gene expression for chromosome 11p15.5. For the same region on 11p15.5, overexpression of paternal alleles and loss of maternal gene expression leads to Beckwith-Wiedemann syndrome (BWS), an overgrowth disorder. Of note, RSS can also be due to maternal UPD for chromosome 7.

As stated above, the alterations at loci that cause imprinting syndromes are diverse and include gain or loss of methylation at either the ICR or another DMR, uniparental disomy, mutation on the active allele, or disruption of regulatory sequences. Each of these changes alters expression of the maternally or paternally expressed imprinted genes. Here we will focus on two of these disorders, BWS and RSS, which are linked in some cases to the same imprinted region at 11 15.5. These disorders demonstrate the opposing effects of imprinted genes on fetal and extraembryonic growth and development.

\section{Beckwith-Wiedemann syndrome and Russell-Silver syndrome}

BWS is the most commonly identified imprinting disorder with a reported incidence of 1/13700 live births and equal incidence in males and females (Pettenati et al., 1986). BWS is characterized by both fetal and extraembryonic overgrowth including macrosomia, macroglossia, visceromegaly, mesenchymal dysplasia, placentomegaly, and increased incidence of embryonic tumors (Choufani et al., 2013). Overgrowth is seen during fetal and postnatal development. Wilms tumors and hepatoblastomas are the most common embryonal tumors seen, with an overall risk of about $7.5 \%$ (DeBaun and Tucker, 1998). RSS is characterized by severe pre- and postnatal growth retardation including short stature with a normal head size, a triangular face with prominent forehead, and skeletal/limb asymmetry (Azzi et al., 2014). Most cases of BWS and RSS are due to genetic and/or epigenetic changes on chromosome 11p15.5 (Fig. 3). Several of the genes in this region are growth regulators and, depending on the nature of the imprinting aberration, lead to either BWS or RSS. Both BWS and RSS are recognized as a spectrum of disorders ranging from mild to severe disease, suggesting that, for some alterations, the changes occur only in a subset of cells.

Gain of methylation (GOM) at IC1 leads to overexpression of the growth factor IGF2 and downregulation of $H 19$, which encodes a ncRNA and microRNA implicated in growth suppression, with a developmental consequence of overgrowth (Azzi et al., 2014). IGF2 encodes a growth factor that is highly expressed in the fetus and placenta from the paternal allele (Monk et al., 2006). Postnatally, IGF2 is biallelically expressed from the liver via a different promoter (Monk et al., 2006). H19 is a maternally expressed ncRNA that is expressed in the endoderm and mesoderm of the embryo and throughout the placenta. After birth, $\mathrm{H} 19$ is silenced in most tissues, except in heart and skeletal muscle. $\mathrm{H} 19$ is evolutionarily conserved and has been speculated to have a role in both tumor formation and tumor suppression (Yoshimizu et al., 2008). Additionally, a microRNA, miR-675, has been identified within the first exon of H19. In mice, this microRNA demonstrates distinct expression patterns from $\mathrm{H} 19$ and is speculated to play a role in placental and postnatal growth (Keniry et al., 2012). About 10\% of BWS patients have GOM at IC1 and they have an increased risk of developing embryonal tumors (Choufani et al., 2013). Loss of methylation (LOM) at IC1, with downregulation of IGF2 expression and $H 19$ overexpression (i.e. biallelic $H 19$ expression) leads to undergrowth and occurs in about $50 \%$ of RSS patients (Azzi et al., 2014). LOM at IC2 is reported in over $50 \%$ of BWS cases (Azzi et al., 2014, Choufani et al., 2013). Aberrant hypomethylation leads to derepression of the ncRNA KCNQ1OT1 on the maternal allele and, as a consequence, loss of expression of CDKN1C and other protein coding genes that are normally expressed on the maternal allele (Azzi et al., 2014, Choufani et al., 2013). CDKN1C is a cyclin-dependent kinase inhibitor of G1 cyclin complexes and acts to negatively regulate cell growth and proliferation. CDKN1C is expressed in both embryo and placenta during development and continues to be expressed postnatally (Jacob et al., 2013). Maternally-inherited loss of function mutations in CDKN1C are reported in about $10 \%$ of BWS patients and about $40 \%$ of familial cases of BWS (Choufani et al., 2013). BWS patients with CDKN1C mutations are more likely to have polydactyly, genital abnormalities, cleft palate and are less likely to develop tumors compared with other molecular causes of BWS, suggesting that decreased CDKN1C expression disrupts development of these organ systems (Kantaputra et al., 2013, Romanelli et al., 2010). Activating mutations in CDKN1C have been reported in RSS patients (Azzi et al., 2014). Chromosomal alterations such as paternal uniparental isodisomy of 11 p15.5 leads to BWS in $20 \%$ of cases while maternal UPD has been reported in one case of RSS (Bullman et al., 2008). Maternal UPD7 has been reported in $5-10 \%$ of RSS. More recently, maternally transmitted microdeletions in IC 1 have been demonstrated to cause familial BWS and are associated with hypermethylation of IC1. Although the phenotype of these patients is similar to GOM at IC1 (Sparago et al., 2004), the relationship between the microdeletion and gain of methylation is not clear. That is, it is not known whether the loss of imprinting at the locus (biallelic IGF2 and reduced H19 expression) is dependent upon the microdeletion, gain of methylation or both. However, anticipation with increased hypermethylation in successive generations correlating with increased severity of BWS phenotype has been reported (Berland etal., 2013). Maternally transmitted IC2 mutations have also been described in one family, leading to hypomethylation and decreased CDKN1C expression (Algar et al., 2011). Finally, paternal transmission of duplications of the entire IC1 and IC2 region can also lead to BWS (Azzi et al., 2014).

Mouse models of the BWS and RSS orthologous regions have provided insight into the epigenetic regulation of this region and its role in embryonic and placental growth. Mouse models overexpressing lgf2 with deletion of Cdkn1c or lgf2r showed fetal phenotypes similar to BWS (Caspary et al., 1999, Eggenschwiler et al., 1997, Sun etal., 1997). Moreover, mice with deletions of the H19/Igf2ICR showed expression and growth trends similar to BWS and RSS depending on paternal or maternal inheritance of the deletions, respectively (Thorvaldsen et al., 1998, Thorvaldsen et al., 2006). 
A model with $\mathrm{CpG}$ mutations preventing maintenance of methylation on the paternal ICR led to decreased Igf2 expression and H19 overexpression with resulting small size as seen in RSS (Engel et al., 2004). It should be noted, however, that none of these models provides the complete BWS or RSS phenotypes, suggesting that either the mouse locus is distinct enough from the human to not demonstrate the full phenotype or there are other regulatory factors contributing to the human phenotypes. It has also been suggested that the rate of growth between human and mouse may account for the differences in phenotype (Caspary et al., 1999).

\section{Genome-wide paternal uniparental disomy}

Surprisingly, several rare case of mosaic genome-wide paternal UPD have been reported (Gogiel et al., 2013, Inbar-Feigenberg et al., 2013, Kalish et al., 2013). While no cases of live-born complete UPD cases have been documented, thirteen mosaic live-born cases have been reported to date. The predominant phenotype is similar to BWS with overgrowth, hemihyperplasia, hyperinsulinism, and a high incidence of tumor development (Kalish et al., 2013). Most patients were premature and had placental overgrowth, which is consistent with the mostly paternally derived tissue observed in androgenetic conceptuses. Additional features of other paternal UPD disorders were observed in some of the cases and included pseudohypoparathyroidism (UPD20) and bell-shaped thoraces (UPD14). Few of the patients had developmental delays or other features of Angelman syndrome (Kalish et al., 2013). All of these patients demonstrated a mosaic mixture of biparental and uniparental cells in each tissue type tested. In some patients, all cell types and tissues tested showed greater than $80 \%$ paternal UPD cells. Importantly, none of the patients showed $100 \%$ paternal UPD in any cell type, which raises the question of how much maternal contribution is needed for viable embryonic development. Moreover, although the basis for the observed phenotypes in the mosaic genome-wide UPD patients is not known, the expressed phenotype likely corresponds to the amount of paternal UPD cells present in a given target tissue (i.e. more paternal UPD in the neuronal cells of mosaic genome-wide paternal UPD patients expressing Angelman syndrome features).

\section{Assisted reproductive technologies and imprinting disorders}

Another growing patient population that questions our understanding of the maintenance and establishment of imprinting is assisted reproductive technologies (ART) conceptions. The timing of ART coincides with both the establishment and maintenance of imprinting. In ART, the egg donor undergoes hormonal hyperstimulation to facilitate release of multiple oocytes; this is the time at which the oocyte is in its growth phase and is being reprogrammed. With respect to imprinting, mouse studies have shown that maternallymethylated ICRs are methylated during oocyte growth, although these ICRs are not methylated simultaneously (Lucifero et al., 2004). The subsequent in vitro fertilization, embryo culture and transfer to mothers also occur when the embryo is undergoing extensive reprogramming. In this case, the embryo undergoes a post-fertilization extensive loss of DNA methylation together with changes in post-translational histone modifications, which prepare the embryo for cleavage divisions and subsequent lineage differen- tiation. Thus, ART manipulations take place during sensitive periods of mammalian development. Several small studies have suggested increased incidence of BWS and AS following ART; however, large studies to confirm the true incidence have not been completed to date (Chang et al., 2005, Odom and Segars, 2010). A recent meta analysis attempting to correlate the results of 8 studies of ART and BWS summarized that 6 of the studies found a positive correlation between BWS and ART and calculated an overall relative risk of 5.2 (Vermeiden and Bernardus, 2013). In several of the individual studies, when decreased fertility in the parents was taken into account, the increased incidence of imprinting disorders in ART was not significant. Increased incidences of RSS, AS, and PWS were not seen but the overall incidences of these disorders are much lower than BWS (Vermeiden and Bernardus, 2013). It should be noted that the vast majority of ART-associated cases of BWS and AS involve loss of ICR methylation. This is especially interesting for AS, where loss of methylation is extremely rare in the population.

Animal models have confirmed that techniques used in ART can cause epigenetic perturbations at imprinted (and other) loci (EI Haj] and Haaf, 2013, Grace and Sinclair, 2009, Laprise, 2009). The animal models have the added attraction that infertility is not a confounding factor. Animal models have tested hormonal hyperstimulation, IVF, embryo culture and transfer, all of which have been associated with aberrant imprinting, including loss of imprinting and loss of ICR methylation. Bovine models demonstrate that ART leads to increased large offspring syndrome with macrosomia, macroglossia, and abdominal wall defects and biallelically expressed imprinted genes seen in BWS (Chen et al., 2013). Interestingly, the ART conceptuses show a much greater imprinting perturbation in the placentas than in embryonic tissues (de Waal et al., 2014). While there are a number of possible explanations for this result, one of the most compelling explanations is that imprinted genes have redundant mechanisms to maintain parental-specific imprinting, including DNA methylation and post-translational histone modifications, in the embryonic lineages whereas extraembryonic tissues are less likely to employ both sets of epigenetic machinery in the maintenance of imprinted gene expression.

\section{Summary and future directions}

Establishment and maintenance of imprinted gene expression is integral for normal embryonic and extraembryonic development. Mis-regulation of this process can occur at many levels and leads to clinical disease. The role of individual genes in each of these imprinted clusters is still being uncovered. Further understanding of the regulation of imprinted genes may lead to improvements in ART and improved management of human imprinting disorders.

\section{Acknowledgements \\ MSB is supported by the National Institutes of Health. JMK is supported by the National Institutes of Health and the Alex's Lemonade Stand Foundation.}

\section{References}

ALGAR, E., DAGAR, V., SEBAJ, M. and PACHTER, N. (2011). An 11p15 Imprinting Centre Region 2 Deletion in a Family with Beckwith Wiedemann Syndrome Provides Insights into Imprinting Control at Cdkn1c. PLoS One 6: e29034.

ANGRIST, M., BOLK, S., BENTLEY, K., NALLASAMY, S., HALUSHKA, M.K. and CHAKRAVARTI, A. (1998). Genomic Structure of the Gene for the Sh2 and Pleckstrin Homology Domain-Containing Protein Grb10 and Evaluation of Its 
Role in Hirschsprung Disease. Oncogene 17: 3065-3070.

ANKOLKAR, M., SALVI, V., WARKE, H., VUNDINTI, B.R. and BALASINOR, N.H. (2013). Methylation Status of Imprinted Genes Dlk1-Gt12, Mest (Peg1), Zac (Plagl1), and Line-1 Elements in Spermatozoa of Normozoospermic Men, Unlike H19 Imprinting Control Regions, Is Not Associated with Idiopathic Recurrent Spontaneous Miscarriages. Fertil. Steril. 99: 1668-1673.

ARNAUD, P., MONK, D., HITCHINS, M., GORDON, E., DEAN, W., BEECHEY, C.V., PETERS, J., CRAIGEN, W., PREECE, M., STANIER, P. et al., (2003). Conserved Methylation Imprints in the Human and Mouse Grb10 Genes with Divergent Allelic Expression Suggests Differential Reading of the Same Mark. Hum Mol Genet 12: 1005-1019.

AZZI, S., ABI HABIB, W. and NETCHINE, I. (2014). Beckwith-Wiedemann and Russell-Silver Syndromes: From New Molecular Insights to the Comprehension of Imprinting Regulation. Curr Opin Endocrinol Diabetes Obes 21: 30-38.

BARTOLOMEI, M.S. (2009). Genomic Imprinting: Employing and Avoiding Epigenetic Processes. Genes Dev 23: 2124-2133.

BARTOLOMEI, M.S. and FERGUSON-SMITH, A.C. (2011). Mammalian Genomic Imprinting. CSH Perspect. Biol 3. (doi: 10.1101/cshperspect.a002592)

BARTON, S.C., SURANI, M.A. and NORRIS, M.L. (1984). Role of Paternal and Maternal Genomes in Mouse Development. Nature 311: 374-376.

BERLAND, S., APPELBACK, M., BRULAND, O., BEYGO, J., BUITING, K., MACKAY, D.J., KAREN TEMPLE, I. and HOUGE, G. (2013). Evidence for Anticipation in Beckwith-Wiedemann Syndrome. Eur J Hum Genet: EJHG 21: 1344-1348.

BULLMAN, H., LEVER, M., ROBINSON, D.O., MACKAY, D.J., HOLDER, S.E. and WAKELING, E.L. (2008). Mosaic Maternal Uniparental Disomy of Chromosome 11 in a Patient with Silver-Russell Syndrome. J Med Genet 45: 396-399.

CASPARY, T., CLEARY, M.A., PERLMAN, E.J., ZHANG, P., ELLEDGE, S.J. and TILGHMAN, S.M. (1999). Oppositely Imprinted Genes P57(Kip2) and Igf2 Interact in a Mouse Model for Beckwith-Wiedemann Syndrome. Genes Dev 13: 3115-3124.

CASSIDY, S.B., SCHWARTZ, S., MILLER, J.L. and DRISCOLL, D.J. (2012). PraderWilli Syndrome. Genet Med 14: 10-26.

CHANG, A.S., MOLEY, K.H., WANGLER, M., FEINBERG, A.P. and DEBAUN, M.R. (2005). Association between Beckwith-Wiedemann Syndrome and Assisted Reproductive Technology: A Case Series of 19 Patients. Fertil. Steril. 83: 349-354.

CHEN, Z., ROBBINS, K.M., WELLS, K.D. and RIVERA, R.M. (2013). Large Offspring Syndrome: A Bovine Model for the Human Loss-of-Imprinting Overgrowth Syndrome Beckwith-Wiedemann. Epigenetics 8: 591-601.

CHOUFANI, S., SHUMAN, C. and WEKSBERG, R. (2013). Molecular Findings in Beckwith-Wiedemann Syndrome. American Journal of Medical Genetics Part $C$, Seminars in Medical Genetics 163: 131-140.

DE WAAL, E., MAK, W., CALHOUN, S., STEIN, P., ORD, T., KRAPP, C., COUTIFARIS, C., SCHULTZ, R.M. and BARTOLOMEI, M.S. (2014). In vitro Culture Increases the Frequency of Stochastic Epigenetic Errors at Imprinted Genes in Placental Tissues from Mouse Concepti Produced through Assisted Reproductive Technologies. Biol Reprod 90: 22.

DEBAUN, M.R. and TUCKER, M.A. (1998). Risk of Cancer During the First Four Years of Life in Children from the Beckwith-Wiedemann Syndrome Registry. J. Pediatrics 132: 398-400.

DOCHERTY, L.E., POOLE, R.L., MATTOCKS, C.J., LEHMANN, A., TEMPLE, I.K. and MACKAY, D.J. (2010). Further Refinement of the Critical Minimal Genetic Region for the Imprinting Disorder 6q24 Transient Neonatal Diabetes. Diabetologia 53: 2347-2351.

DOWDY, S.C., GOSTOUT, B.S., SHRIDHAR, V., WU, X., SMITH, D.I., PODRATZ, K.C. and JIANG, S.W. (2005). Biallelic Methylation and Silencing of Paternally Expressed Gene 3 (Peg3) in Gynecologic Cancer Cell Lines. Gynecol Oncol 99: 126-134.

EGGENSCHWILER, J., LUDWIG, T., FISHER, P., LEIGHTON, P.A., TILGHMAN, S.M. and EFSTRATIADIS, A. (1997). Mouse Mutant Embryos Overexpressing Igf-li Exhibit Phenotypic Features of the Beckwith-Wiedemann and SimpsonGolabi-Behmel Syndromes. Genes Dev 11: 3128-3142.

EL HAJJ, N. and HAAF, T. (2013). Epigenetic Disturbances in in vitro Cultured Gametes and Embryos: Implications for Human Assisted Reproduction. Fertil Steril 99: 632-641.

ENGEL, N., WEST, A.G., FELSENFELD, G. and BARTOLOMEI, M.S. (2004). Antagonism between DNA Hypermethylation and Enhancer-Blocking Activity at the H19 Dmd Is Uncovered by Cpg Mutations. Nat Genet 36: 883-888.
GAO, Y., ZHANG, H.D., LIN, J.S., ZHANG, M.P. and ZHANG, R.G. (2010). [the Imprinting Status of Genetic Imprinted Gene Peg10 in Human Hepatocellular Carcinomas]. Zhonghua Gan Zang Bing Za Zhi 18: 894-899.

GOGIEL, M., BEGEMANN, M., SPENGLER, S., SOELLNER, L., GORETZLEHNER, U., EGGERMANN, T. and STROBL-WILDEMANN, G. (2013). Genome-Wide Paternal Uniparental Disomy Mosaicism in a Woman with Beckwith-Wiedemann Syndrome and Ovarian Steroid Cell Tumour. Eur. J. Human Genet. 21: 788-791.

GRACE, K.S. and SINCLAIR, K.D. (2009). Assisted Reproductive Technology, Epigenetics, and Long-Term Health: A Developmental Time Bomb Still Ticking. Semin Reprod Med 27: 409-416.

GU, T.P., GUO, F., YANG, H., WU, H.P., XU, G.F., LIU, W., XIE, Z.G., SHI, L., HE, X., JIN, S.G. et al., (2011). The Role of Tet3 DNA Dioxygenase in Epigenetic Reprogramming by Oocytes. Nature 477: 606-610.

HUANG, J., ZHANG, X., ZHANG, M., ZHU, J.D., ZHANG, Y.L., LIN, Y., WANG, K.S., QI, X.F., ZHANG, Q., LIU, G.Z. et al., (2007). Up-Regulation of Dlk1 as an Imprinted Gene Could Contribute to Human Hepatocellular Carcinoma. Carcinogenesis 28: 1094-103.

HYSI, P.G., YOUNG, T.L., MACKEY, D.A., ANDREW, T., FERNANDEZMEDARDE, A., SOLOUKI, A.M., HEWITT, A.W., MACGREGOR, S., VINGERLING, J.R., LI, Y.J. et al., (2010). A Genome-Wide Association Study for Myopia and Refractive Error Identifies a Susceptibility Locus at 15q25. Nat Genet 42: 902-905.

IGLESIAS-PLATAS, I., COURT, F., CAMPRUBI, C., SPARAGO, A., GUILLAUMETADKINS, A., MARTIN-TRUJILLO, A., RICCIO, A., MOORE, G.E. and MONK, D. (2013). Imprinting at the Plagl1 Domain Is Contained within a 70Kb Ctcf/ Cohesin-Mediated Non-Allelic Chromatin Loop. Nucleic Acid. Res. 41:2171-2179.

INBAR-FEIGENBERG, M., CHOUFANI, S., CYTRYNBAUM, C., CHEN, Y.A., STEELE, L., SHUMAN, C., RAY, P.N. and WEKSBERG, R. (2013). Mosaicism for GenomeWide Paternal Uniparental Disomy with Features of Multiple Imprinting Disorders: Diagnostic and Management Issues. Am. J. Medical Genet. Part A 161A: 13-20.

JACOB, K., ROBINSON, W. and LEFEBVRE, L. (2013). Beckwith-Wiedemann and Silver-Russell Syndromes: Opposite Developmental Imbalances in Imprinted Regulators of Placental Function and Embryonic Growth. Clinical Genet. 84: 326-334.

JORGENSEN, L.H., SELLATHURAI, J., DAVIS, E.E., THEDCHANAMOORTHY, T., AL-BADER, R.W., JENSEN, C.H. and SCHRODER, H.D. (2013). Delta-Like 1 Homolog (Dlk1): A Marker for Rhabdomyosarcomas Implicated in Skeletal Muscle Regeneration. PLoS One 8: e60692.

KALISH, J.M., CONLIN, L.K., BHATTI, T.R., DUBBS, H.A., HARRIS, M.C., IZUMI, K., MOSTOUFI-MOAB, S., MULCHANDANI, S., SAITTA, S., STATES, L.J. et al., (2013). Clinical Features of Three Girls with Mosaic Genome-Wide Paternal Uniparental Isodisomy. American journal of medical genetics PartA161A: 1929-1939.

KAMIKIHARA, T., ARIMA, T., KATO, K., MATSUDA, T., KATO, H., DOUCHI, T., NAGATA, Y., NAKAO, M. and WAKE, N. (2005). Epigenetic Silencing of the Imprinted Gene Zac by DNA Methylation Is an Early Event in the Progression of Human Ovarian Cancer. Int J Cancer 115: 690-700.

KANEDA, M., OKANO, M., HATA, K., SADO, T., TSUJIMOTO, N., LI, E. and SASAKI, H. (2004). Essential Role for De Novo DNA Methyltransferase Dnmt3a in Paternal and Maternal Imprinting. Nature 429: 900-903.

KANTAPUTRA, P.N., SITTIWANGKUL, R., SONSUWAN, N., ROMANELLI, V., TENORIO, J. and LAPUNZINA, P. (2013). A Novel Mutation in Cdkn1c in Sibs with Beckwith-Wiedemann Syndrome and Cleft Palate, Sensorineural Hearing Loss, and Supernumerary Flexion Creases. Am. J. Medical Genet. PartA 161A: 192-197.

KAWAKAMI, T., CHANO, T., MINAMI, K., OKABE, H., OKADA, Y. and OKAMOTO, K. (2006). Imprinted Dlk1 Is a Putative Tumor Suppressor Gene and Inactivated by Epimutation at the Region Upstream of Gt12 in Human Renal Cell Carcinoma. Hum Mol Genet 15: 821-830

KENIRY, A., OXLEY, D., MONNIER, P., KYBA, M., DANDOLO, L., SMITS, G. and REIK, W. (2012). The H19 Lincrna Is a Developmental Reservoir of Mir-675 That Suppresses Growth and Igf1r. Nat Cell Biol 14: 659-665.

KOBAYASHI, S., KOHDA, T., MIYOSHI, N., KUROIWA, Y., AISAKA, K., TSUTSUMI, O., KANEKO-ISHINO, T. and ISHINO, F. (1997). Human Peg1/Mest, an Imprinted Gene on Chromosome 7. Hum Mol Genet 6: 781-786.

LAPRISE, S.L. (2009). Implications of Epigenetics and Genomic Imprinting in Assisted Reproductive Technologies. Mol Reprod Dev 76: 1006-1018.

LATOS, P.A., PAULER, F.M., KOERNER, M.V., SENERGIN, H.B., HUDSON, Q.J., STOCSITS, R.R., ALLHOFF, W., STRICKER, S.H., KLEMENT, R.M., WARCZOK, K.E. et al., (2012). Airn Transcriptional Overlap, but Not Its Lncrna Products, Induces Imprinted Igf2r Silencing. Science 338: 1469-1472. 
LECUMBERRI, B., FERNANDEZ-REBOLLO, E., SENTCHORDI, L., SAAVEDRA, P., BERNAL-CHICO, A., PALLARDO, L.F., BUSTOS, J.M., CASTANO, L., DE SANTIAGO, M., HIORT, O. et al., (2010). Coexistence of Two Different Pseudohypoparathyroidism Subtypes (la and Ib) in the Same Kindred with Independent Gs\{Alpha\} Coding Mutations and Gnas Imprinting Defects. J Med Genet 47: 276-280.

LEE, J.T. and BARTOLOMEI, M.S. (2013). X-Inactivation, Imprinting, and Long Noncoding Rnas in Health and Disease. Cell 152: 1308-1323.

LEWIS, A., MITSUYA, K., UMLAUF, D., SMITH, P., DEAN, W., WALTER, J., HIGGINS, M., FEIL, R. and REIK, W. (2004). Imprinting on Distal Chromosome 7 in the Placenta Involves Repressive Histone Methylation Independent of DNA Methylation. Nat Genet 36: 1291-1295.

LI, X., ITO, M., ZHOU, F., YOUNGSON, N., ZUO, X., LEDER, P. and FERGUSONSMITH, A.C. (2008). A Maternal-Zygotic Effect Gene, Zfp57, Maintains Both Maternal and Paternal Imprints. Dev Cell 15: 547-557.

LINGLART, A., MAUPETIT-MEHOUAS, S. and SILVE, C. (2013). Gnas-Related Lossof-Function Disorders and the Role of Imprinting. Horm Res Paediatr 119-129.

LUCIFERO, D., MANN, M.R., BARTOLOMEI, M.S. and TRASLER, J.M. (2004). Gene-Specific Timing and Epigenetic Memory in Oocyte Imprinting. Hum $\mathrm{Mol}$ Genet 13: 839-849.

MABB, A.M., JUDSON, M.C., ZYLKA, M.J. and PHILPOT, B.D. (2011). Angelman Syndrome: Insights into Genomic Imprinting and Neurodevelopmental Phenotypes. Trends Neurosci. 34: 293-303.

MACKAY, D.J., CALLAWAY, J.L., MARKS, S.M., WHITE, H.E., ACERINI, C.L., BOONEN, S.E., DAYANIKLI, P., FIRTH, H.V., GOODSHIP, J.A., HAEMERS, A.P. et al., (2008). Hypomethylation of Multiple Imprinted Loci in Individuals with Transient Neonatal Diabetes Is Associated with Mutations in Zfp57. Nat Genet 40: 949-951.

MCGRATH, J. and SOLTER, D. (1984). Inability of Mouse Blastomere Nuclei Transferred to Enucleated Zygotes to Support Development in Vitro. Science 226: 1317-1319.

MONK, D., SANCHES, R., ARNAUD, P., APOSTOLIDOU, S., HILLS, F.A., ABUAMERO, S., MURRELL, A., FRIESS, H., REIK, W., STANIER, P. et al., (2006). Imprinting of Igf2 P0 Transcript and Novel Alternatively Spliced Ins-Igf2 Isoforms Show Differences between Mouse and Human. Hum Mol Genet 15: 1259-1269.

NAGANO, T., MITCHELL, J.A., SANZ, L.A., PAULER, F.M., FERGUSON-SMITH, A.C., FEIL, R. and FRASER, P. (2008). The Air Noncoding Rna Epigenetically Silences Transcription by Targeting G9a to Chromatin. Science 322: 1717-1720.

NAKAMURA, T., LIU, Y.J., NAKASHIMA, H., UMEHARA, H., INOUE, K., MATOBA, S., TACHIBANA, M., OGURA, A., SHINKAI, Y. and NAKANO, T. (2012). Pgc7 Binds Histone H3k9me2 to Protect against Conversion of $5 \mathrm{mc}$ to $5 \mathrm{hmc}$ in Early Embryos. Nature 486: 415-419.

ODOM, L.N. and SEGARS, J. (2010). Imprinting Disorders and Assisted Reproductive Technology. Curr Opin Endocrinol Diabetes Obes 17: 517-522.

OKINO, K., KONISHI, H., DOI, D., YONEYAMA, K., OTA, Y., JIN, E., KAWANAMI, O. and TAKESHITA, T. (2005). Up-Regulation of Growth Factor Receptor-Bound Protein 10 in Cervical Squamous Cell Carcinoma. Oncol Rep 13: 1069-1074.

PETTENATI, M.J., HAINES, J.L., HIGGINS, R.R., WAPPNER, R.S., PALMER, C.G. and WEAVER, D.D. (1986). Wiedemann-Beckwith Syndrome: Presentation of Clinical and Cytogenetic Data on 22 New Cases and Review of the Literature. Hum Genet. 74: 143-154.

QUENNEVILLE, S., VERDE, G., CORSINOTTI, A., KAPOPOULOU, A., JAKOBSSON, J., OFFNER, S., BAGLIVO, I., PEDONE, P.V., GRIMALDI, G., RICCIO, A. et al., (2011). In Embryonic Stem Cells, Zfp57/Kap1 Recognize a Methylated Hexanucleotide to Affect Chromatin and DNA Methylation of Imprinting Control Regions. Mol Cell 44: 361-372.

ROMANELLI, V., BELINCHON, A., BENITO-SANZ, S., MARTINEZ-GLEZ, V., GRACIABOUTHELIER, R., HEATH, K.E., CAMPOS-BARROS, A., GARCIAMINAUR, S. FERNANDEZ, L., MENESES, H. et al., (2010). Cdkn1c (P57(Kip2)) Analysis in Beckwith-Wiedemann Syndrome (Bws) Patients: Genotype-Phenotype Correlations, Novel Mutations, and Polymorphisms. Am J Med GenetA 152A: 1390-1397.

SOLTER, D. (1988). Differential Imprinting and Expression of Maternal and Paternal Genomes. Annu Rev Genet 22: 127-146.
SOLTER, D. (1998). Imprinting. Int J Dev Biol 42: 951-954.

SPARAGo, A., CERRATO, F., VERNUCCI, M., FERRERO, G.B., SILENGO, M.C and RICCIO, A. (2004). Microdeletions in the Human H19 Dmr Result in Loss of Igf2 Imprinting and Beckwith-Wiedemann Syndrome. Nature Genet. 36: 958-960.

SUN, F.L., DEAN, W.L., KELSEY, G., ALLEN, N.D. and REIK, W. (1997). Transactivation of Igf2 in a Mouse Model of Beckwith-Wiedemann Syndrome. Nature 389: 809-815.

SUTTON, V.R. and SHAFFER, L.G. (2000). Search for Imprinted Regions on Chromosome 14: Comparison of Maternal and Paternal Upd Cases with Cases of Chromosome 14 Deletion. Am. J. Med. Genet. 93: 381-387.

TAKAMARU, H., YAMAMOTO, E., SUZUKI, H., NOJIMA, M., MARUYAMA, R. YAMANO, H.O., YOSHIKAWA, K., KIMURA, T., HARADA, T., ASHIDA, M. et al, (2012). Aberrant Methylation of Rasgrf1 Is Associated with an Epigenetic Field Defect and Increased Risk of Gastric Cancer. CancerPrev Res (Phila) 5: 1203-1212.

TARNOWSKI, M., SCHNEIDER, G., AMANN, G., CLARK, G., HOUGHTON, P., BARR F.G., KENNER, L., RATAJCZAK, M.Z. and KUCIA, M. (2012). Rasgrf1 Regulates Proliferation and Metastatic Behavior of Human Alveolar Rhabdomyosarcomas. Int J Oncol 41: 995-1004.

THORVALDSEN, J.L., DURAN, K.L. and BARTOLOMEI, M.S. (1998). Deletion of the H19 Differentially Methylated Domain Results in Loss of Imprinted Expression of H19 and Igf2. Genes \& Development 12: 3693-3702.

THORVALDSEN, J.L., FEDORIW, A.M., NGUYEN, S. and BARTOLOMEI, M.S. (2006). Developmental Profile of H19 Differentially Methylated Domain (Dmd) Deletion Alleles Reveals Multiple Roles of the Dmd in Regulating Allelic Expression and DNAMethylation at the Imprinted H19/Igf2 Locus. Molec. Cell. Biol. 26: 1245-1258.

TROUILLARD, O., AGUIRRE-CRUZ, L., HOANG-XUAN, K., MARIE, Y., DELATTRE, J.Y. and SANSON, M. (2004). Parental 19q Loss and Peg3 Expression in Oligodendrogliomas. Cancer Genet Cytogenet 151: 182-183.

TSOU, A.P., CHUANG, Y.C., SU, J.Y., YANG, C.W., LIAO, Y.L., LIU, W.K., CHIU, J.H. and CHOU, C.K. (2003). Overexpression of a Novel Imprinted Gene, Peg10, in Human Hepatocellular Carcinoma and in Regenerating Mouse Livers. J Biomed Sci 10: 625-635.

TURAN, S. and BASTEPE, M. (2013). The Gnas Complex Locus and Human Diseases Associated with Loss-of-Function Mutations or Epimutations within This Imprinted Gene. Horm Res Paediatr 80: 229-241.

UMLAUF, D., GOTO, Y., CAO, R., CERQUEIRA, F., WAGSCHAL, A., ZHANG, Y. and FEIL, R. (2004). Imprinting Along the Kcnq1 Domain on Mouse Chromosome 7 Involves Repressive Histone Methylation and Recruitment of Polycomb Group Complexes. Nat Genet 36: 1296-1300.

VAN DEN VEYVER, I.B., NORMAN, B., TRAN, C.Q., BOURJAC, J. and SLIM, R. (2001). The Human Homologue (Peg3) of the Mouse Paternally Expressed Gene 3 (Peg3) Is Maternally Imprinted but Not Mutated in Women with Familia Recurrent Hydatidiform Molar Pregnancies. J Soc Gynecol Investig 8: 305-313.

VERMEIDEN, J.P. and BERNARDUS, R.E. (2013). Are Imprinting Disorders More Prevalent after Human in vitro Fertilization or Intracytoplasmic Sperm Injection? Fertil. Steril. 99: 642-651.

WEAVER, J.R., SARKISIAN, G., KRAPP, C., MAGER, J., MANN, M.R. and BARTOLOMEI, M.S. (2010). Domain-Specific Response of Imprinted Genes to Reduced Dnmt1. Mol Cell Biol 30: 3916-3928.

WEAVER, J.R., SUSIARJO, M. and BARTOLOMEI, M.S. (2009). Imprinting and Epigenetic Changes in the Early Embryo. Mamm Genome 20: 532-543.

WILLIAMSON, C., BLAKE, A., THOMAS, S., BEECHEY, C., HANCOCK, J., CATTANACH, B. and PETERS, J. (2014). World Wide Web Site - Mouse Imprinting Data and References-Http://Www.Har.Mrc.Ac.Uk/Research/Genomic_Imprinting/, (ed. Oxfordshire: MRC Harwell.

YOSHIMIZU, T., MIROGLIO, A., RIPOCHE, M.A., GABORY, A., VERNUCCI, M., RICCIO, A., COLNOT, S., GODARD, C., TERRIS, B., JAMMES, H. et al., (2008). The H19 Locus Acts in vivo as a Tumor Suppressor. Proc Natl Acad Sci U S A 105: 12417-12422.

ZHU, Q., WANG, L., XIAO, Z., XIAO, F., LUO, J., ZHANG, X., PENG, X., WANG, X. and SUN, H. (2013). Decreased Expression of Ras-Grf1 in the Brain Tissue of the Intractable Epilepsy Patients and Experimental Rats. Brain Res 1493: 99-109. 


\section{Further Related Reading, published previously in the Int. J. Dev. Biol.}

DNA methylation establishment during oocyte growth: mechanisms and significance Shin-Ichi Tomizawa, Joanna Nowacka-Woszuk and Gavin Kelsey

Int. J. Dev. Biol. (2012) 56: 867-875

http://dx.doi.org/10.1387/ijdb.120152gk

Regulation of germ cell meiosis in the fetal ovary

Cassy M. Spiller, Josephine Bowles and Peter Koopman

Int. J. Dev. Biol. (2012) 56: 779-787

http://dx.doi.org/10.1387/ijdb.120142pk

A possible role of Reproductive homeobox 6 in primordial germ cell differentiation Chang Liu, Paichi Tsai, Ana-Marie García, Brandon Logeman and Tetsuya S. Tanaka Int. J. Dev. Biol. (2011) 55: 909-916

http://dx.doi.org/10.1387/ijdb.113342cl

DNA methylation reprogramming and DNA repair in the mouse zygote

Konstantin Lepikhov, Mark Wossidlo, Julia Arand and Jörn Walter

Int. J. Dev. Biol. (2010) 54: 1565-1574

http://dx.doi.org/10.1387/ijdb.103206kl

Role of mitochondrial DNA replication during differentiation of reprogrammed stem cells Richard D.W. Kelly and Justin C. St. John

Int. J. Dev. Biol. (2010) 54: 1659-1670

http://dx.doi.org/10.1387/ijdb.103202rk

\section{Nuclear reprogramming in zygotes}

Chanchao Lorthongpanich, Davor Solter and Chin Yan Lim

Int. J. Dev. Biol. (2010) 54: 1631-1640

http://dx.doi.org/10.1387/ijdb.103201cl

Natural and artificial routes to pluripotency

Winfried $\mathrm{H}$. Krueger, Lindsey C. Swanson, Borko Tanasijevic and Theodore P. Rasmussen Int. J. Dev. Biol. (2010) 54: 1545-1564

http://dx.doi.org/10.1387/ijdb.103199wk

Faithful reprogramming to pluripotency in mammals - what does nuclear transfer teach us?

Julien Maruotti, Alice Jouneau and Jean-Paul Renard

Int. J. Dev. Biol. (2010) 54: 1609-1621

http://dx.doi.org/10.1387/ijdb.103195jm

5 yr ISI Impact Factor $(2011)=2.959$
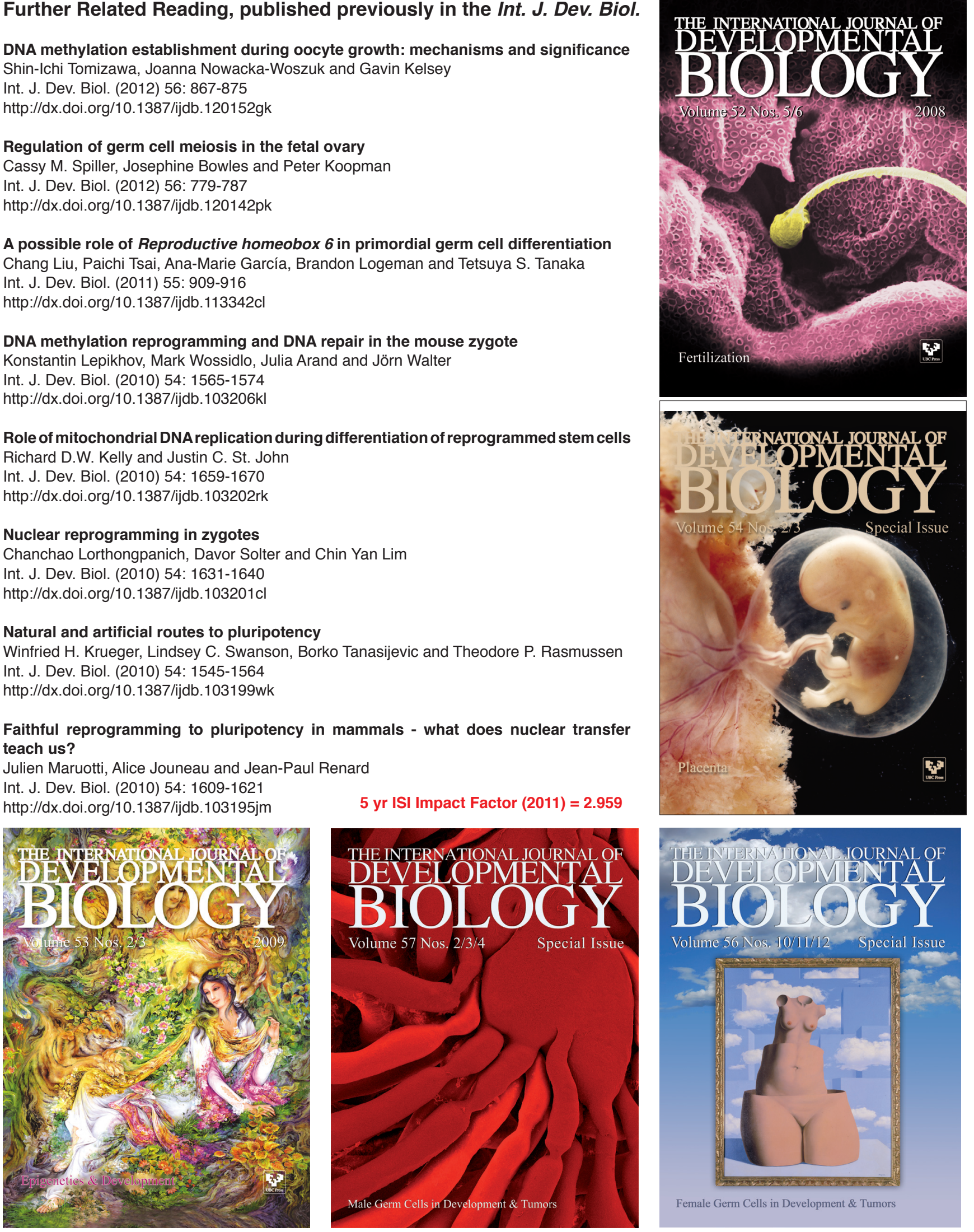